Cad. Líng. Lit. Hebr., n. 15, p. 280-305, 2017

\title{
OS CAMPOS DE CONCENTRAÇÃO ${ }^{1}$
}

Hannah Arendt

Tradução: Rafael Rocca dos Santos*

A SS fez do campo a sociedade mais totalitária existente até agora

- David Rousset.

I

Há três abordagens possíveis para a realidade do campo de concentração: a experiência de sofrimento imediato do prisioneiro, a recordação do sobrevivente e a antecipação temerosa daqueles que temem o campo de concentração como uma possibilidade para o futuro.

A experiência imediata é expressa nos relatos que "relatam mas não comunicam" coisas que escapam à compreensão e à experiência humanas, coisas que, portanto, quando padecidas por homens, transformam-nos em "animais conformados" (The Dark Side of the Moon, Nova York, 1947). Há diversos relatos desse tipo feitos por sobreviventes, mas somente alguns foram publicados, em parte porque, bastante compreensivelmente, o mundo não quer ouvir mais sobre essas coisas, em parte porque todos eles deixam o leitor impassível, isto é, tão apático e

\footnotetext{
${ }^{1} \mathrm{O}$ texto sobre os Campos de Concentração de Hannah Arendt encontra-se on-line sem menção aos direitos autorais no site do Howard Gotlieb Archival Research Center da Universidade de Boston. Da Universidade de Boston os editors da Cadernos receberam a seguinte mensagem: Boston University has copyright to each issue of the magazine as a whole and to individual articles published in Partisan Review. The University has no objection, to the extent of its rights, to your nonexclusive, royalty-free use of the article in the manner cited in your email. Sincerely, Laura Russo Manager of Public Service and Donor Relations, Howard Gotlieb Archival Research Center, Boston University.

* Formado em Direito e Letras, Português e Alemão, pela Universidade de São Paulo. Atualmente, pesquisador de Mestrado em Teoria Literária e Literatura Comparada na FFLCH-USP. É tradutor de inglês, alemão e latim e Diretor da Casa Brasileira Fernando Pessoa.
} 
ARENDT, Hannah. Os campos de concentração

desconcertado quanto o próprio escritor, e fracassam em inspirar aquelas paixões de indignação e simpatia pelas quais os homens sempre se mobilizaram por justiça, pois "uma miséria profunda demais não suscita compaixão, mas repugnância e ódio" (Rousset).

Der SS-Staat, de Eugen Kogon, e Les Jours de notre mort, de David Rousset, são produtos de recordação assimilada. Ambos os autores têm escrito conscientemente para o mundo dos vivos, ambos desejam se fazer compreendidos a qualquer custo, e ambos abandonaram o desdém insano por aqueles "que nunca passaram por isso", o que tão amiúde substitui a comunicação em relatos diretos. Essa boa vontade consciente é a única garantia de que aqueles que retornaram não irão, depois de um breve período de irado ressentimento contra a humanidade em geral, adaptar-se ao mundo real e novamente se tornar os mesmos tolos inocentes que eram quando entraram nos campos. Os dois livros são indispensáveis para uma compreensão não somente dos campos de concentração, mas também do regime totalitário como um todo. Eles se tornam inúteis e até mesmo perigosos tão logo ensaiam uma interpretação positiva - Kogon porque cita precedentes históricos claros e acredita que os campos podem ser entendidos psicologicamente, Rousset porque busca consolo em uma “experiência extrema", em um tipo de sofrimento que, estritamente falando, não mais admite a experiência e assim chega a uma afirmação inexpressiva da vida que é extremamente perigosa porque romantiza e transfigura o que nunca deve, sob quaisquer circunstâncias, ser repetido 
Cad. Líng. Lit. Hebr., n. 15, p. 280-305, 2017

neste mundo ${ }^{1}$. O que realmente é verdade, ao contrário, foi recentemente afirmado por Isaac Rosenfeld no The New Leader (14 de fevereiro de 1948):

ainda não compreendemos o que aconteceu aos judeus da Europa, e talvez nunca iremos... Por agora, sabemos tudo o que se pode saber. Mas não serve... pois não há resposta boa o bastante para estar à altura dos fatos que o provocaram. Nada há senão embotamento, e a respeito de embotamento, nós... não somos diferentes dos assassinos que foram adiante, e fizeram suas coisas, e não prestaram atenção aos gritos.

A antecipação temerosa é a abordagem mais difundida e talvez a única apropriada para a realidade do campo de concentração. Certamente tem bastante a ver com as atitudes dos homens sob domínio totalitário, apesar de sempre parecer andar de mãos dadas com uma incerteza notável e muito característica que impede tanto a rebelião quanto qualquer compreensão clara e articulada da coisa temida. Kogon relata

somente muitíssimos poucos daqueles que entravam em um campo de concentração pela primeira vez tinham uma parca noção... do que os esperava. [Alguns] estavam preparados para o pior. Mas essas ideias eram sempre imprecisas; a realidade as ultrapassava em muito.

A razão para a incerteza era precisamente que essa realidade era totalmente inacreditável e inconcebível. Em regimes totalitários, a incerteza, bem como o medo, é fabricada e estimulada

\footnotetext{
${ }^{1}$ Que o vitalismo puramente literário de Rousset pudesse sobreviver aos anos em Buchenwald pareceria uma prova evidente da tese de Kogon de que "a maioria dos prisioneiros [deixou] os campos de concentração com exatamente as mesmas convicções que tinham antes; na verdade, tais convicções se tornaram mais acentuadas" (p. 302). David Rousset conclui as 702 páginas de horror, o que prova muitas vezes que é possível matar a humanidade de um homem sem matar seu corpo, com um curto parágrafo de "triunfo" que soa como se tivesse sido escrito por um picareta literário que nunca colocara os pés fora de Paris. "Nunca blasfemamos contra a vida. Nossos sistemas de mundo não eram parecidos, mas, mais profundamente, mais remotamente, nossa afirmação do poder e da grandeza criativa da vida, nossa fé absoluta em seu triunfo, permaneceu intacta. Pois, coletivamente, é sua mais alta e mais forte expressão do gesto vital na história do universo". Não é surpreendente que esse "gesto vital" tenha atraído Georges Bataille e sua teoria da "experiência extrema" -, no entanto, é um tanto surpreendente que os proponentes do extremo e da falta de sentido não tenham mudado de opinião diante de uma realidade que ultrapassava todos os seus sonhos. Bataille (Critique, outubro de 1947) escreve: "Uma das reações mais inesperadas de Rousset é sua exaltação, quase ao ponto da euforia, ante à ideia de participar de uma experiência que não fazia sentido. Nada poderia ser mais viril, mais saudável". A tradução [ao inglês] provém de Instead ( $\left.\mathrm{n}^{\circ} 1,1948\right)$; não pareceria ser acidente que essa reflexão pseudoprofunda fosse o primeiro romper do silêncio que os intelectuais mantiveram sobre todo esse assunto.
} 
ARENDT, Hannah. Os campos de concentração

pelo tratamento propagandístico da instituição do terror. "Não havia quase nada ligado à SS que não fosse mantido em segredo. $\mathrm{O}$ maior segredo de todos era a rotina dos campos de concentração... cujo único propósito era espalhar um terror anônimo com uma natureza política geral" (Kogon). Os campos de concentração e tudo a eles ligado sistematicamente se tornam públicos e, ao mesmo tempo, são mantidos em segredo absoluto. São usados como ameaça, mas todos os relatos em si acerca deles são suprimidos e denunciados como fantasia.

Não é de surpreender que aqueles que fizeram do terror o verdadeiro fundamento de seu poder deveriam saber como explorá-lo por meio da publicidade e da propaganda. $\mathrm{O}$ surpreendente é que os efeitos psicológicos e políticos dessa propaganda conseguiram sobreviver ao colapso do regime nazista e à abertura dos campos de concentração. Poder-se-ia pensar que os relatos de testemunhas e, a um grau mais elevado, os trabalhos de recordação organizada que substanciam uns ao outros e conversam diretamente com o leitor, com mais persuasão no caso de Rousset, deveriam ter invalidado a alegação propagandística de que tais coisas eram histórias absurdas de horror. Esse, como sabemos todos, não é o caso. Apesar de provas em abundância, qualquer pessoa que fale ou escreva sobre os campos de concentração ainda é considerada um suspeito; e se o falante retornou decididamente ao mundo dos vivos, ele próprio é frequentemente atacado por dúvidas a respeito de sua própria honestidade, como se tivesse confundido um pesadelo com a vida real.

Essa dúvida das pessoas acerca de si mesmas e da realidade de sua própria experiência somente revela o que os nazistas sempre souberam: que os homens determinados a cometer crimes acharão oportuno organizá-los na escala mais vasta e improvável. Não somente porque isso retrata todas as punições determinadas pelo sistema legal como inadequadas e absurdas, mas porque a própria imensidão dos crimes garante que se acreditará mais prontamente nos 
Cad. Líng. Lit. Hebr., n. 15, p. 280-305, 2017

assassinos que proclamam sua inocência com todo tipo de mentiras do que nas vítimas que contam a verdade.

Os nazistas nem mesmo consideraram necessário manter essa descoberta para si mesmos. Hitler circulou milhões de cópias de seu livro, no qual ele afirma que, para ter sucesso, uma mentira precisa ser enorme - o que não impediu as pessoas de acreditarem nele, assim como, de maneira similar, as proclamações dos nazistas, repetidas ad nauseam, de que os judeus seriam exterminados como percevejos (i.e., com gás venenoso) não impediram que as pessoas não acreditassem nelas.

Há uma grande tentação em livrar com explicações o intrinsicamente inacreditável por meio de racionalizações generosas. Em cada um de nós espreita tal generosidade, adulando-nos com a voz do senso comum. Tentamos entender elementos no presente ou experiências rememoradas que simplesmente ultrapassam nossos poderes de compreensão. Tentamos classificar como criminosa uma coisa que, como todos sentimos, nenhuma categoria jamais pretendeu abarcar. Que significado tem o conceito de assassinato quando somos confrontados com a produção em massa de cadáveres? Tentamos entender o comportamento dos prisioneiros de campos de concentração e de homens da SS psicologicamente, quando o próprio fato a ser percebido é que a psique (ou o caráter) pode ser destruída até mesmo sem a destruição do homem físico e que, por certo, como Rousset demonstra convincentemente, a psique, o caráter ou a individualidade parecem, sob certas circunstâncias, exprimir-se somente através da rapidez ou da lentidão pela qual se desintegram. O resultado final, em qualquer caso, são homens inanimados, i.e., homens que não podem mais ser entendidos psicologicamente, cujo retorno ao mundo humano psicologicamente, ou senão inteligivelmente, lembra à risca a ressurreição de Lázaro - conforme Rousset indica no título de seu livro. Todas as afirmações de senso comum, sejam de natureza psicológica ou sociológica, servem apenas para encorajar aqueles 
ARENDT, Hannah. Os campos de concentração

que as pensam "superficiais" para "habitar os horrores" (Georges Bataille, em Critique, janeiro de 1948).

Se é verdade que os campos de concentração são a instituição mais importante do regime totalitário, "habitar os horrores" pareceria indispensável para a compreensão do totalitarismo. Mas a recordação não consegue fazê-lo mais do que o relato não comunicativo consegue. Nos dois gêneros há uma tendência inerente a fugir da experiência; instintiva ou racionalmente, ambos os tipos de escritor são muito atentos ao abismo terrível que separa o mundo dos vivos daquele dos mortos-vivos, que eles não podem fornecer nada mais senão uma série de acontecimentos lembrados que devem parecer tão inacreditáveis àqueles que os relatam quanto ao seu público. Somente a imaginação temerosa daqueles que foram estimulados por tais relatos, mas que não foram de fato castigados em sua própria carne, daqueles que estão consequentemente livres do terror bestial e desesperado, o qual, quando confrontados com o horror real e presente, inexoravelmente paralisa tudo o que não é uma mera reação, pode se permitir a continuar a pensar em tais horrores.

Tais pensamentos são úteis somente para a percepção de contextos políticos e a mobilização de paixões políticas. Uma mudança de personalidade de qualquer tipo não pode ser mais induzida pelo pensar nos horrores do que pela experiência real do horror. A redução de um homem a um feixe de reações o separa - tão radicalmente quanto uma doença mental de tudo o que dentro dele seja personalidade ou caráter. Quando, como Lázaro, ele ascende dos mortos, encontra sua personalidade ou seu caráter inalterados, exatamente como ele os deixou.

Nem pode o horror ou o pensar nos horrores se tornar uma base para uma comunidade política ou um partido, em sentido mais estrito. Falharam tentativas de criar uma elite europeia com um programa de compreensão intereuropeu baseado na experiência comum de um campo de concentração, bem como, no mesmo sentido, tentativas similares depois da primeira guerra 
Cad. Líng. Lit. Hebr., n. 15, p. 280-305, 2017

falharam em tirar consequências políticas a partir da experiência do soldado no front. Em ambos os casos, revelou-se que as experiências em si poderiam transmitir somente superficialidades niilistas, tais como

A vítima e o carrasco são ignóbeis da mesma maneira; a lição dos campos é a irmandade da abjeção; se você não agiu com o mesmo grau de ignomínia, é somente porque você não teve tempo... mas a podridão subjacente que se eleva, eleva, eleva, é absolutamente, e terrivelmente, a mesma. (Rousset)

Consequências políticas, como o pacifismo do pós-guerra, resultaram do medo universal da guerra, não da experiência da guerra. Uma visão, regida e mobilizada por medo, sobre a estrutura da guerra moderna não teria levado a um pacifismo desprovido de realidade, mas à visão de que o único terreno aceitável para a guerra moderna é lutar contra condições sob as quais nós não queremos mais viver - e nosso conhecimento dos campos e das câmaras de tortura de regimes totalitários nos convenceu deveras de que tais condições são possíveis. Uma visão sobre a natureza do regime totalitário, guiado pelo nosso medo do campo de concentração, poderia servir para desvalorizar todos os matizes políticos antiquados da esquerda à direita e, ao lado e acima deles, introduzir o critério político mais essencial para julgar os eventos de nossa época: isso levará ou não ao regime totalitário?

De qualquer forma, a antecipação temerosa tem a grande vantagem de dissipar as interpretações sofístico-dialéticas da política, as quais se assentam todas na superstição de que algum bem pode provir do mal. Tais acrobacias dialéticas retiveram ao menos uma aparência de justificativa desde que o pior mal que o homem pudesse infligir fosse o assassinato. Mas o assassinato, como sabemos hoje, é ainda um mal limitado. $\mathrm{O}$ assassino que mata um homem que deve morrer de qualquer maneira se move dentro do reino familiar da vida e da morte, entre os quais há uma relação necessária que é a base da dialética, apesar de os dialéticos não estarem sempre atentos a isso. $\mathrm{O}$ assassino deixa um cadáver e não alega que sua vítima nunca existiu; 
ARENDT, Hannah. Os campos de concentração

ele pode ocultar os traços de sua própria identidade, mas ele não oblitera a memória e o pesar daqueles que amaram sua vítima; ele destrói uma vida, mas ele não destrói o fato em si de ela nunca ter existido.

O horror dos campos de concentração e de extermínio nunca poderá ser completamente abarcado pela imaginação exatamente porque jaz fora da vida e da morte. Os prisioneiros são mais efetivamente isolados do mundo dos vivos do que se estivessem mortos, pois o terror força o esquecimento entre aqueles que os conheceram ou os amaram. "Que mulheres extraordinárias vocês têm aqui", exclamou a polícia soviética quando mulheres polonesas insistiam em saber o paradeiro de seus maridos que haviam desaparecido. "Em nosso país, quando o marido é preso, a esposa entra com divórcio e procura outro homem" (The Dark Side of the Moon).

O assassinato nos campos é tão impessoal quanto esmagar um mosquito, uma simples técnica de gerenciamento, como quando um campo está superlotado e é liquidado - ou um subproduto acidental, como quando um prisioneiro sucumbe à tortura. Tortura e inanição sistemáticas criam uma atmosfera de morte permanente na qual a morte, bem como a vida, é efetivamente dificultada.

O medo do Mal absoluto que não admite escapatória sabe que esse é o fim das evoluções e dos desenvolvimentos dialéticos. Sabe que a política moderna gira em torno de uma pergunta que, estritamente falando, nunca deveria entrar na política, a questão de tudo ou nada: tudo, isto é, uma sociedade humana rica de possibilidades infinitas; ou precisamente nada, isto é, o fim da humanidade. 
Cad. Líng. Lit. Hebr., n. 15, p. 280-305, 2017

Não há paralelos à vida dos campos de concentração. Todos os aparentes paralelos criam confusão e distraem a atenção do que é essencial. O trabalho forçado oferece momentaneamente comparações proveitosas, mas, ao examinar de perto, levam a lugar algum.

O trabalho forçado como punição está limitado quanto ao tempo e à intensidade. O condenado retém seus direitos sobre seu corpo; ele não é absolutamente torturado e ele não é absolutamente dominado. $\mathrm{O}$ banimento bane somente de uma parte do mundo para outra parte do mundo também habitada por seres humanos; não exclui completamente do mundo humano. Por toda a história, a escravidão tem sido uma instituição dentro de uma ordem social; os escravos não eram, como os prisioneiros dos campos de concentração, retirados da vista e, portanto, da proteção de seus companheiros; como instrumentos de trabalho, eles tinham um preço definido e, como propriedade, tinham um valor definido. O prisioneiro do campo de concentração não tem preço porque sempre pode ser substituído e não pertence a ninguém. Do ponto de vista de uma sociedade normal, ele é absolutamente supérfluo, apesar de ser utilizado para o trabalho em tempos de escassez aguda de mão de obra, como na Rússia e na Alemanha durante a guerra.

O campo de concentração enquanto instituição não foi estabelecido para fins de quaisquer rendimentos possíveis de mão de obra; a única função econômica permanente dos campos foi o financiamento de seu próprio aparato de supervisão; assim, do ponto de vista econômico, os campos de concentração existem principalmente para seus próprios fins. Qualquer trabalho, sob circunstâncias diferentes, poderia ter sido executado de maneira muito melhor e com menos custos $^{2}$.

\footnotetext{
${ }^{2}$ Kogon tem o seguinte a dizer sobre as condições de trabalho nos campos nazistas, que presumivelmente eram mais organizados desse ponto de vista do que aqueles da União Soviética: "Uma grande parte do trabalho forçado nos campos de concentração era inútil; ou era supérflua ou era tão miseravelmente planejada que tinha de ser feita duas ou três vezes. Construções tinham amiúde de ser iniciadas diversas vezes porque as fundações desabavam" (p. 58). Quanto às condições russas, até mesmo Dallin (Forced Labor in Soviet Union, p. 105), que construiu todo seu livro adotando a tese de que o propósito dos campos russos era fornecer trabalho barato, é forçado a admitir:
} 
O exemplo da Rússia, a cujos campos de concentração amiúde se aludem como campos de trabalho forçado - porque a burocracia soviética lhes deu esse título lisonjeiro - mostra o mais claramente possível que o principal não é o trabalho forçado; trabalho forçado é a condição normal de todo o proletariado russo que foi privado de liberdade de movimento e pode ser mobilizado em qualquer lugar a qualquer tempo.

O caráter inacreditável dos horrores está intimamente ligado com sua inutilidade econômica. Os nazistas levaram essa inutilidade ao ponto de uma antiutilidade aberta quando, em meio à guerra, apesar da escassez de material rodante, transportaram milhões de judeus para o leste e montaram enormes e dispendiosas fábricas de extermínio. Em meio a um mundo estritamente utilitário, a contradição óbvia entre esses atos e os gastos militares conferiu a todo esse empreendimento um ar de irrealidade insana.

Entretanto, tal irrealidade, criada por uma falta de propósito aparente, é a própria base de todas as formas de campos de concentração. Vistos de fora, eles e as coisas que acontecem dentro deles podem ser descritos somente por imagens desenhadas de uma vida após a morte, isto é, uma vida demovida de propósitos terrenos. Campos de concentração podem muito habilmente ser divididos em três tipos, correspondendo a três concepções ocidentais básicas de uma vida após a morte: Hades, purgatório e inferno. Ao Hades correspondem aquelas formas brandas, antigamente populares até mesmo em países não totalitários por tirar da frente elementos indesejáveis de todo tipo - refugiados, apátridas, antissociais e os desempregados; como nos campos de deslocados, que nada são além de campos para pessoas que se tornaram supérfluas ou incômodas, eles sobreviveram à guerra. O purgatório é representado pelos campos de trabalho da União Soviética, onde a negligência é combinada com o trabalho forçado caótico.

\footnotetext{
"Na verdade, a eficiência do trabalho forçado, apesar de incentivos e coerções, era e é extremamente baixa. A eficiência média de um trabalhador escravo ficava com certeza 50 por cento abaixo daquela de um trabalhador russo livre, cuja produtividade, por sua vez, nunca foi alta".
} 
Cad. Líng. Lit. Hebr., n. 15, p. 280-305, 2017

Inferno, no sentido mais literal, é encarnado por aqueles tipos de campos aperfeiçoados pelos nazistas, nos quais o todo da vida foi completa e sistematicamente organizado tendo em vista o maior tormento possível.

Todos os três tipos têm uma coisa em comum: as massas humanas trancafiadas neles são tratadas como se não mais existissem, como se o que acontecera a elas não fosse mais do interesse de ninguém, como se elas já estivessem mortas e algum espírito maligno e enlouquecido estivesse se regozijando em estacioná-las por um momento entre a vida e a morte antes de lhas consentirem a paz eterna.

Não é tanto o arame farpado, mas a irrealidade habilmente fabricada daqueles quem ele encarcera que provoca essas enormes crueldades e, no fim, faz o extermínio parecer uma medida perfeitamente normal. Tudo o que foi feito dentro dos campos nos é conhecido a partir de um mundo de fantasias perversas e maliciosas. O difícil de entender é que, como tais fantasias, esses crimes repulsivos aconteceram em um mundo fantasmagórico, em um mundo em que não havia consequências ou responsabilidades; e, finalmente, nem os atormentadores, nem os atormentados, e menos ainda os de fora, podiam ter noção de que o que estava acontecendo era qualquer coisa senão um jogo cruel ou um sonho absurdo.

Os filmes que os Aliados circularam na Alemanha e em outros lugares depois da guerra mostraram claramente que essa atmosfera de insanidade e irrealidade não é dissipada pelo relato escrito puro. Ao observador imparcial, eles são tão convincentes quanto as fotos de substâncias misteriosas tiradas em sessões espíritas. O senso comum reagiu aos horrores de Buchenwald e Auschwitz com o argumento plausível: "que crime essas pessoas devem ter cometido para que tais coisas fossem feitas a elas!”, ou, na Alemanha e na Áustria, em meio à inanição, superpopulação e ódio generalizado: “pena que eles pararam de matar os judeus a gás”, e em toda parte com o dar de ombros cético dirigido a propagandas ineficazes. 
ARENDT, Hannah. Os campos de concentração

Se a propaganda da verdade fracassa em convencer o filisteu médio precisamente porque é monstruosa demais, é certamente perigosa àqueles que sabiam, a partir de sua própria imaginação, que eles mesmos são capazes de realizar tais coisas e estão, portanto, perfeitamente inclinados a acreditar na realidade do que viram. De repente, torna-se evidente que coisas que a imaginação humana baniu por milhares de anos para um reino além da competência humana podem ser fabricadas bem aqui na Terra. Inferno e purgatório, e mesmo uma sombra de sua duração perpétua, podem ser estabelecidos pelos mais modernos métodos de destruição e terapia. Quando pessoas desse tipo, que são muito mais numerosas em qualquer cidade grande do que gostaríamos de pensar, assistem a esses filmes ou leem relatos das mesmas coisas, o pensamento que vêm às suas mentes é o de que o poder do homem é muito maior do que eles jamais ousaram pensar, e que homens podem realizar fantasias infernais sem fazer o céu desabar ou a terra se abrir.

A única coisa que não pode ser reproduzida é o que tornou as concepções tradicionais de inferno toleráveis ao homem: o Julgamento Final, a ideia de um padrão absoluto de justiça combinado com a possibilidade infinita da graça. Pois, na avaliação humana, não há crime e pecado comensurável aos tormentos eternos do inferno. Daí o embaraço do senso comum, que pergunta: que crime essas pessoas devem ter cometido para sofrer tão inumanamente? Daí também a inocência absoluta das vítimas: nenhum homem jamais mereceu isso. Daí, finalmente, o acaso grotesco com o qual as vítimas dos campos de concentração foram escolhidas no estado de terror aperfeiçoado: tal "punição" pode, com iguais justiça e injustiça, ser imposta a qualquer um.

III 
Cad. Líng. Lit. Hebr., n. 15, p. 280-305, 2017

Comparando com o insano resultado final - a sociedade do campo de concentração -, o processo pelo qual homens são preparados para esse fim, e os métodos pelos quais os indivíduos são adaptados a essas condições, são transparentes e lógicos. A fabricação em massa de cadáveres é precedida pela preparação histórica e politicamente inteligível de cadáveres ambulantes.

Em outro vínculo, poderia ser possível, e de fato necessário, descrever esse processo preparatório como uma consequência das sublevações políticas de nosso século. O ímpeto e, o que é mais importante, o consentimento tácito a tais condições sem precedentes no coração da Europa são os produtos daqueles acontecimentos que, em um período de desintegração política, repentina e inesperadamente deixaram centenas de milhares de seres humanos sem casa, sem pátria, ilegais e indesejados, enquanto milhões de seres humanos foram tornados pelo desemprego economicamente supérfluos e socialmente onerosos. Isso, por sua vez, somente pôde acontecer porque os direitos do homem, que nunca haviam sido filosoficamente estabelecidos, mas meramente formulados, que nunca haviam sido politicamente assegurados, mas meramente proclamados, perderam, em sua forma tradicional, toda a validade.

Enquanto isso, entretanto, regimes totalitários exploraram esses desenvolvimentos para seus próprios fins. Para entender tais fins, devemos examinar por completo o processo de se preparar cadáveres ambulantes. Afinal, a perda de passaporte, de residência e do direito de trabalhar era apenas uma preparação temporária e simples, a qual poderia ter produzido resultados adequados.

O primeiro passo essencial foi matar o sujeito de direito no homem; isso foi feito ao se colocar o campo de concentração fora do sistema penal normal e ao selecionar seus prisioneiros fora do processo legal normal, pelo qual um crime definido acarreta uma pena previsível. Assim, criminosos, que, por outras razões, são um elemento essencial em uma sociedade de 
ARENDT, Hannah. Os campos de concentração

campo de concentração, são normalmente enviados para um campo somente ao cumprir sua sentença prisional. Desvios dessa regra na Rússia devem ser atribuídos à escassez catastrófica de prisões e a um desejo, ainda irrealizado, de transformar todo o sistema penal em um sistema de campos de concentração.

A inclusão de criminosos é necessária para tornar plausível a alegação propagandística de que a instituição existe para elementos antissociais. É igualmente essencial, desde que haja um sistema penal no país, que eles sejam enviados aos campos somente ao cumprir sua sentença, isto é, quando têm de fato o direito à sua liberdade. É, paradoxalmente, mais difícil matar o sujeito de direito em um homem que é culpado de algum crime do que em um homem totalmente inocente. Apátridas que em todos os países da Europa perderam seus direitos civis junto com sua nacionalidade aprenderam isso bastante bem; sua posição legal melhorava automaticamente assim que cometiam um roubo: então, não ficavam mais sem direitos, tinham os mesmos direitos de todos os outros ladrões. Para matar o sujeito de direito no homem, o campo de concentração não deve, em nenhuma circunstância, tornar-se uma punição calculável para crimes definidos. Criminosos não pertencem propriamente a campos de concentração; se, ainda assim, eles perfazem a única categoria permanente entre os prisioneiros, é uma concessão do estado totalitário aos preconceitos da sociedade que conseguirá, dessa maneira, acostumarse mais prontamente à existência dos campos. A amalgamação de criminosos com todas as outras categorias tem, além disso, a vantagem de tornar surpreendentemente evidente para todos os outros que estão chegando o fato de que aterrissaram no nível mais baixo da sociedade. Logo se verifica que, para não haver dúvida, eles têm todo motivo em invejar o mais baixo ladrão e assassino; mas, entrementes, o nível mais baixo é um bom começo. Além disso, é um meio 
Cad. Líng. Lit. Hebr., n. 15, p. 280-305, 2017

efetivo de camuflagem: isso acontece somente a criminosos e nada pior está acontecendo do que merecidamente acontece a criminosos ${ }^{3}$.

Em toda parte, os criminosos constituem a aristocracia dos campos (na Alemanha, durante a guerra, eles foram substituídos na liderança pelos comunistas, porque nem mesmo um mínimo de trabalho racional podia ser feito sob as condições caóticas criadas por uma administração criminosa. Isso foi meramente uma transformação temporária dos campos de concentração em campos de trabalhos forçados, um fenômeno totalmente atípico e com duração limitada. Com sua experiência limitada, de tempos de guerra, dos campos de concentração nazistas, Rousset superestima a influência e o poder dos comunistas). O que coloca os criminosos na liderança não é tanto a afinidade entre o pessoal da supervisão e elementos criminosos - na União Soviética, aparentemente, os supervisores não são, como a SS, a elite especial de criminosos quanto o fato de que somente foram enviados ao campo criminosos ligados a alguma atividade definida e que neles, consequentemente, a destruição do sujeito de direito não pode ter sucesso completo, já que sabem ao menos por que estão em um campo de concentração. Para os presos políticos, isso é apenas subjetivamente verdade; suas ações, conquanto sejam ações e não meras opiniões ou suspeitas vagas de alguém, ou associação acidental a um grupo politicamente condenável, não são, por via de regra, abrangidas pelo sistema legal normal do país e não são definidas juridicamente.

Foi acrescentado ao amálgama de políticos e criminosos, com os quais os campos de concentração na Rússia e na Alemanha começaram, um terceiro elemento, em um período inicial, que logo constituiria a maioria de todos os prisioneiros dos campos de concentração.

\footnotetext{
3 “A Gestapo e a SS sempre deram grande importância em misturar as categorias de prisioneiros nos campos. Em campo algum os prisioneiros pertenciam exclusivamente a uma categoria” (Kogon, p. 19). Na Rússia, sempre foi costume, desde o início, misturar prisioneiros políticos e criminosos. Durante os primeiros dez anos de poder soviético, os grupos políticos de esquerda gozavam de certos privilégios comparados aos contrarrevolucionários e criminosos. Mas, "depois do fim da década de vinte, os presos políticos eram até mesmo oficialmente tratados como inferiores a criminosos comuns" (Dallin, p. 177 e ss.).
} 
ARENDT, Hannah. Os campos de concentração

Esse grupo, o maior, consistiu desde então de pessoas que nada tinham feito e que, seja por sua própria consciência ou pela consciência de seus torturadores, não tinham ligação racional alguma com sua prisão. Na Alemanha, depois de 1938, esse elemento foi representado pelas massas de judeus; na Rússia, por grupos que, por nenhum motivo relacionado à suas ações, incorreram no desfavor das autoridades. Esses grupos, inocentes em todos os sentidos, são os mais aptos à completa experimentação da cassação de direitos e à destruição do sujeito de direito e, portanto, são tanto qualitativa quanto quantitativamente a categoria mais essencial da população do campo. Esse princípio foi mais completamente concretizado nas câmaras de gás que, se apenas devido à sua enorme capacidade, não poderiam ser planejadas para casos individuais mas somente para o povo em geral. Nessa ligação, o diálogo seguinte sumariza a situação do indivíduo: "Para quê, se posso perguntar, existem as câmaras de gás?”, "Para que você nasceu?" (Rousset). É esse terceiro grupo dos totalmente inocentes que, em todo caso, passa mais dificuldade nos campos. Criminosos e presos políticos são assimilados a essa categoria; privados assim da distinção de proteção que advém de eles terem feito algo, estão totalmente expostos ao arbitrário.

Contrastando com o acaso completo pelo qual os prisioneiros são selecionados estão as categorias, sem sentido em si mesmas mas úteis do ponto de vista da organização, nas quais eles são normalmente divididos ao chegar. Nos campos alemães havia criminosos, presos políticos, elementos antissociais, transgressores religiosos e judeus, todos distinguidos por símbolos. Quando os franceses criaram campos de concentração após a guerra civil espanhola, imediatamente introduziram o típico amálgama totalitário entre políticos e criminosos e inocentes (nesse caso, apátridas), e que, apesar de sua inexperiência, provaram-se notavelmente engenhosos em criar categorias de prisioneiros sem sentido. Originalmente criadas para prevenir qualquer crescimento de solidariedade entre os prisioneiros, essa técnica se provou 
Cad. Líng. Lit. Hebr., n. 15, p. 280-305, 2017

particularmente valiosa porque ninguém podia saber se sua própria categoria era melhor ou pior do que a de outra pessoa. Na Alemanha, a esse edifício eternamente mutável, apesar de organizado de maneira pedante, foi dada uma aparência de solidez pelo fato de que, sob quaisquer circunstâncias, os judeus perfaziam a categoria mais baixa. A parte pavorosa e grotesca disso era que os prisioneiros se identificavam com essas categorias, como se elas representassem um último vestígio autêntico de sua condição de sujeitos de direito. Não é de surpreender que um comunista de 1933 deva ter saído dos campos mais comunista do que quando entrou, um judeu mais judeu.

Enquanto a classificação dos prisioneiros em categorias é uma medida apenas tática e organizacional, a seleção arbitrária das vítimas indica um princípio essencial da instituição. Se os campos de concentração tinham sido dependentes da existência de adversários políticos, eles mal teriam conseguido sobreviver os primeiros anos em regimes totalitários. “Os campos teriam morrido se, ao realizar suas prisões, a Gestapo tivesse considerado apenas o princípio da oposição" (Kogon). Mas a existência de uma oposição política é, para um sistema de campo de concentração, somente um pretexto, e o propósito do sistema não é alcançado mesmo quando colocado sob o mais monstruoso terror; a população torna-se mais ou menos coordenada voluntariamente, i.e., abre mão de seus direitos políticos. O objetivo de um sistema arbitrário é destruir os direitos civis de toda a população, a qual, por fim, torna-se tão fora da lei em seu próprio país quanto os apátridas e os desabrigados. A destruição dos direitos de um homem, o assassinato do sujeito de direito nele, é um pré-requisito para dominá-lo por completo. Pois até mesmo o livre consentimento é um obstáculo; e isso se aplica não apenas a categorias especiais tais como criminosos, adversários políticos, judeus, mas a todo habitante de um estado totalitário. 
ARENDT, Hannah. Os campos de concentração

Qualquer restrição, até mesmo a mais tirânica, a essa persecução arbitrária a certas opiniões de natureza religiosa ou política, a certos modos de comportamento intelectual ou erótico-social, a certos “crimes” recém-inventados, tornaria os campos, ao contrário, supérfluos porque a longo prazo nenhuma atitude ou opinião pode resistir à ameaça de tanto terror; e, acima de tudo, desenvolver-se-ia para um novo sistema de justiça que, dada qualquer estabilidade, não fracassaria em produzir um novo sujeito de direito no homem que ludibriaria a dominação totalitária. Os chamados "Volksnutzen" dos nazistas, constantemente volúveis (porque o que é útil hoje pode ser prejudicial amanhã), e a linha eternamente mutável da União Soviética, que, sendo retroativa, quase diariamente tornava novos grupos de pessoas disponíveis para os campos de concentração, são a única garantia para a existência contínua dos campos de concentração e, portanto, para a contínua e total cassação dos direitos do homem.

\section{IV}

O próximo passo decisivo para a preparação de cadáveres ambulantes é o assassinato da pessoa moral no homem. Isso é feito principalmente ao tornar o martírio, pela primeira vez na história, impossível. Rousset escreve:

Quantas pessoas aqui ainda acreditam que um protesto tem uma importância até mesmo histórica? Esse ceticismo é a verdadeira obra prima da SS. Sua maior conquista. Eles corromperam toda a solidariedade humana. Aqui, a noite caiu sobre o futuro. Quando não houver mais nenhuma testemunha, não haverá testemunhos. Protestar quando a morte não mais pode ser adiada é uma tentativa de conferir um significado à morte, agir para além da própria morte. Para ter sucesso, um gesto deve ter significado social. Há centenas de milhares de nós aqui, todos vivendo em solidão absoluta. É por isso que estamos subjugados, não importa o que aconteça.

Os campos e o assassinato de adversários políticos são apenas parte do esquecimento organizado que não apenas abarca portadores da opinião pública, tais como a palavra escrita e falada, mas se estende até mesmo às famílias e aos amigos da vítima. Pesar e recordação são 
Cad. Líng. Lit. Hebr., n. 15, p. 280-305, 2017

proibidos. Na União Soviética, uma mulher entrará com divórcio imediatamente após a prisão do marido para salvar as vidas de seus filhos; se seu marido por acaso voltar, ela o mandará embora de casa com indignação. O mundo ocidental tem até aqui concedido ao inimigo morto, mesmo em seus períodos mais obscuros, o direito de ser lembrado como um reconhecimento autoevidente do fato de que todos somos homens (e apenas homens). É só porque Aquiles partiu para o funeral de Heitor, somente porque os governos mais despóticos honraram o inimigo morto, somente porque os romanos permitiram aos cristãos escrever suas histórias de martírios, somente porque a Igreja manteve vivos seus hereges na memória dos homens que tudo não foi perdido e nunca poderia ser perdido. Os campos de concentração, ao tornar a própria morte anônima - na União Soviética é quase impossível até mesmo descobrir se um prisioneiro está vivo ou morto -, roubaram da morte o significado que ela sempre foi possível ter. De certa forma, eles tiraram do indivíduo a própria morte, provando que dali em diante nada pertencia a ele, e ele não pertencia a ninguém. Sua morte meramente endossou o fato de que ele nunca realmente existiu.

Esse ataque à pessoa moral poderia ter sido ainda contraposto pela consciência do homem, que lhe diz que é melhor morrer como uma vítima do que viver como um burocrata do assassinato. Os governos totalitários extirparam a pessoa moral dessa escapada individualista ao tornar as decisões da consciência absolutamente questionáveis e equivocadas.

Quando um homem encara a alternativa entre trair e dessa maneira assassinar seus amigos ou mandar sua esposa e filhos, pelos quais ele é em todos os sentidos o responsável, à sua morte; quando até mesmo o suicídio significaria o assassinato imediato de sua própria família - como ele deve decidir? A alternativa não é mais entre bem e mal, mas entre assassinato e assassinato. Talvez no único artigo que realmente chegue ao âmago desse assunto, Camus (em Twice a Year, 
ARENDT, Hannah. Os campos de concentração

1947) conta a história de uma mulher na Grécia a quem foi permitido, pelos nazistas, escolher qual entre seus filhos seria assassinado.

Por meio da criação de condições sob as quais a consciência deixa de ser suficiente e fazer o bem se torna completamente impossível, a cumplicidade conscientemente organizada dos regimes totalitários é estendida às vítimas e assim tornada realmente total. A SS envolvia prisioneiros de campos de concentração - criminosos, presos políticos, judeus - em seus crimes ao torná-los responsáveis por uma grande parte da administração, assim os confrontando com o dilema impossível de ou enviar suas famílias para a morte, ou ajudar a assassinar outros homens que por acaso eram desconhecidos.

Uma vez que a pessoa moral foi assassinada, a única coisa que ainda impede os homens de serem transformados em cadáveres ambulantes é a diferenciação do indivíduo, sua identidade única. Em uma forma estéril, tal individualidade pode ser preservada por um estoicismo persistente, e é certo que muitos homens, sob regime totalitários, refugiaram-se e ainda estão todo dia se refugiando nesse isolamento absoluto de uma personalidade sem direitos ou consciência. Não há dúvida de que essa parte da pessoa humana, precisamente porque depende tão essencialmente da natureza e das forças que não podem ser controladas pela vontade, é a mais difícil de se destruir (e, quando destruída, é facilmente consertada).

Os métodos de lidar com essa singularidade da pessoa humana são numerosos e não devemos tentar listá-los. Começam com as condições monstruosas dos transportes aos campos, quando centenas de seres humanos são comprimidos em vagões de gado completamente nus, colados uns nos outros e transportados para lá e para cá pelo país durante vários dias; continuam, ao chegar no campo, com o choque bem organizado das primeiras horas, o raspar da cabeça, a vestimenta grotesca do campo; e os métodos terminam nas torturas absolutamente 
Cad. Líng. Lit. Hebr., n. 15, p. 280-305, 2017

inimagináveis calibradas para não matar o corpo, de toda forma não rapidamente. O objetivo de todos esses métodos, de qualquer modo, é manipular o corpo humano - com suas infinitas possibilidades de sofrimento - de uma forma que cause a destruição da pessoa humana tão inexoravelmente quanto certas doenças mentais de origem orgânica.

É aqui que a completa insânia de todo o processo se torna mais aparente. A tortura, não há dúvida, é uma característica essencial de todo o aparato policial e judicial totalitário; é utilizada todos os dias para fazer as pessoas falarem. Esse tipo de tortura, pois que almeja um objetivo definido e racional, tem certas limitações: ou o prisioneiro fala dentro de um certo tempo, ou ele é morto. Mas a essa tortura conduzida racionalmente outro tipo, irracional e sádico, foi acrescentado nos primeiros campos de concentração nazistas nos porões da Gestapo. Realizada em sua maioria pela SA, não tinha objetivos e não era sistemática, mas dependia da iniciativa de elementos predominantemente anormais. A mortalidade era tão alta que somente alguns prisioneiros dos campos de concentração de 1933 sobreviveram a esses primeiros anos. Esse tipo de tortura parecia ser não tanto uma instituição política calculada quanto uma concessão do regime a seus elementos criminosos e anormais os quais eram, assim, recompensados por serviços prestados. Por trás da bestialidade cega da SA, havia amiúde um ódio profundo e um ressentimento contra todos aqueles que eram social, intelectual e fisicamente melhores do que eles mesmos, e que, agora, como se realizando seus sonhos mais selvagens, estavam em seu poder. Esse ressentimento, que nunca feneceu inteiramente nos campos, parece-nos como um último resquício de sentimento humanamente compreensível.

$\mathrm{O}$ verdadeiro horror começou, entretanto, quando a SS assumiu a administração dos campos. A bestialidade velha e espontânea deu lugar a uma destruição absolutamente fria e sistemática de corpos humanos, calculada para destruir a dignidade humana; a morte era evitada e adiada indefinidamente. Os campos não eram mais parques de diversão para bestas em forma 
humana, isto é, para homens que realmente pertenciam a manicômios ou prisões; o reverso tornou-se verdadeiro: eles foram transformados em “campos de exercício militar” (Kogon), nos quais homens perfeitamente normais eram treinados para ser membros experientes da SS.

$\mathrm{O}$ assassinato da individualidade do homem, da singularidade moldada em partes iguais pela natureza, pela vontade e pelo destino, que se tornou uma premissa tão autoevidente para todas as relações humanas que até mesmo gêmeos idênticos inspiram certo desconforto, cria um horror que ofusca imensamente o ultraje do sujeito de direito e do sujeito político e o desespero da pessoa moral. É esse horror que dá origem a generalizações niilistas as quais sustentam de maneira bastante plausível que, essencialmente, todos os homens se assemelham a bestas. Na verdade, a experiência dos campos de concentração de fato mostra que seres humanos podem ser transformados em exemplares de bestas humanas e que a "natureza" do homem é somente "humana" até o ponto em que se abre a ele a possibilidade de se tornar algo muito não natural, ou seja, um homem.

Depois do assassinato da pessoa moral e da aniquilação do sujeito de direito, a destruição da individualidade é quase sempre bem-sucedida. É concebível que possam ser encontradas algumas leis da psicologia de massas para explicar por que milhões de seres humanos se permitiram marchar sem resistência às câmaras de gás, apesar de que essas leis explicariam nada mais do que a destruição da individualidade. É mais significativo que aquelas pessoas individualmente condenadas à morte muito raramente tentassem levar um de seus carrascos junto com eles, que pouco houve revoltas sérias, e que, mesmo no momento da libertação, houve muitos poucos massacres espontâneos de homens da SS. Pois destruir a individualidade é destruir a espontaneidade, o poder do homem de começar algo novo com seus próprios recursos, algo novo que não pode ser explicado com base nas reações ao ambiente e aos acontecimentos. Portanto, nada resta senão marionetes horríveis com rostos humanos, que se 
Cad. Líng. Lit. Hebr., n. 15, p. 280-305, 2017

comportam como o cachorro nos experimentos de Pavlov, que reagem com confiança perfeita mesmo a caminho de suas próprias mortes, e que nada fazem senão reagir. Este é o verdadeiro triunfo do sistema:

O triunfo da SS requer que a vítima torturada se permita ser conduzida ao nó corredio sem protestar, que ele renuncie e se abandone ao ponto de parar de afirmar sua identidade. E não é gratuito. Não é por nada, por puro sadismo, que os homens da SS desejem essa derrota. Eles sabem que o sistema que tem sucesso em destruir sua vítima antes que suba ao cadafalso... é incomparavelmente o melhor para manter um povo inteiro sob escravidão. Submisso. Nada é mais terrível do que essas procissões de seres humanos caminhando como bonecos às suas mortes. $\mathrm{O}$ homem que vê isso diz a si mesmo: "para que eles sejam reduzidos assim, que poder deve estar escondido nas mãos dos donos", e ele se afasta, cheio de amargura, porém derrotado. (Rousset)

$\mathbf{V}$

É uma característica do terror totalitário que ele aumente à medida que o regime se torna mais estabelecido; pelo mesmo critério, os campos de concentração expandem à medida que a oposição política diminui ${ }^{4}$. Demandas totalitárias não parecem ser satisfeitas pelo sucesso político de estabelecer um estado monopartidário, e parece como se a oposição política não fosse de maneira alguma a causa do terror, mas uma barreira para seu desenvolvimento completo. Isso parece absurdo somente se aplicamos a movimentos totalitários modernos aqueles padrões de utilidade que eles próprios rejeitam expressamente como obsoletos, sentimentais e burgueses.

Se, ao invés, levarmos aspirações totalitárias a sério e nos recusarmos a sermos ludibriados pela afirmação de senso comum de que são utópicos e irrealizáveis, revela-se que a

\footnotetext{
${ }^{4}$ Isso é evidente tanto na Rússia quanto na Alemanha. Na Rússia, os campos de concentração, que foram originalmente planejados para inimigos do regime, começaram a inflar depois de 1930, i.e., em uma época em que não apenas toda a resistência armada tinha sido reprimida, mas também quando toda oposição a Stálin dentro do Partido havia sido liquidada. Nos primeiros anos, havia na Alemanha no máximo dez campos, com um total de não mais do que dez mil prisioneiros. Toda resistência eficaz contra os nazistas acabou ao final de 1936. Mas, ao irromper da guerra, havia mais de uma centena de campos de concentração que, após 1940, pareciam ter contido uma população média de um milhão de prisioneiros.
} 
ARENDT, Hannah. Os campos de concentração

sociedade dos que morrem, estabelecida nos campos, é a única forma de sociedade na qual é possível dominar o homem por completo. Aqueles que aspiram à total dominação devem liquidar toda espontaneidade, assim como a mera existência da individualidade sempre o fará, e encontrá-la em suas formas mais privadas independentemente do quanto apolítico e inofensivo elas possam parecer. O cachorro de Pavlov, o espécime humano reduzido às reações mais elementares, o feixe de reações que sempre pode ser liquidado e substituído por outros feixes de reações que se comportam exatamente da mesma maneira, é o "cidadão" modelo de um estado totalitário; e tal cidadão pode ser produzido, fora dos campos, somente imperfeitamente.

A inutilidade dos campos, sua antiutilidade cinicamente aceita, é somente aparente. Na realidade, eles são mais essenciais à preservação do poder do regime do que quaisquer outras de suas instituições. Sem os campos de concentração, sem o medo indefinido que eles causam e o treinamento muito bem definido que eles oferecem à dominação totalitária, que em nenhum outro lugar foi tão completamente testada em todas as suas mais radicais possibilidades, um estado totalitário não consegue inspirar fanatismo em suas tropas nucleares nem manter todo um povo em completa apatia. Os dominadores e os dominados mergulhariam rápido demais na "velha rotina burguesa"; depois dos primeiros "excessos", eles sucumbiriam à vida cotidiana com suas leis humanas; em suma, eles se desdobrariam na direção à qual todos os observadores, aconselhados pelo senso comum, estavam tão inclinados a adivinhar. A falácia trágica de todas essas profecias originárias de um mundo que ainda era seguro era supor que havia uma tal coisa como uma natureza humana estabelecida desde sempre, identificar essa natureza humana com a história e, assim, declarar que a ideia de dominação total não era somente desumana, mas também irreal. Entrementes, aprendemos que o poder do homem é tão grande que ele realmente pode ser o que desejar ser. 
Cad. Líng. Lit. Hebr., n. 15, p. 280-305, 2017

Está na própria natureza dos regimes totalitários exigir poder ilimitado. Tal poder pode ser assegurado se literalmente todos os homens, sem uma única exceção, sejam dominados com segurança em todos os aspectos de suas vidas. No reino das relações exteriores, novos territórios neutros devem ser constantemente subjugados, enquanto que, em casa, grupos humanos sempre novos devem ser controlados em campos de concentração que expandem ou, quando as circunstâncias o exigem, ser liquidados para abrir espaço a outros. Aqui, a questão da oposição não tem importância tanto em relações exteriores quanto interiores. Qualquer neutralidade, de fato qualquer amizade espontaneamente travada, é, do ponto de vista da dominação totalitária, tão perigosa quanto a hostilidade declarada, precisamente porque a espontaneidade enquanto tal, com sua natureza incalculável, é o maior dos obstáculos à dominação total sobre o homem. Os comunistas de países não comunistas, que fugiram ou foram convocados a Moscou, aprenderam amargamente por experiência que constituíam uma ameaça à União Soviética. Comunistas convencidos são, nesse sentido, o que por si só não encontra realidade hoje, tão ridículos e tão ameaçadores para o regime na Rússia quanto, por exemplo, os nazistas convencidos da facção de Röhm o eram para os nazistas.

O que torna qualquer tipo de convicção e opinião tão ridículo e perigoso sob condições totalitárias é que regimes totalitários se orgulham ao máximo em não precisar deles ou de qualquer ajuda humana de qualquer tipo. Os homens, na medida em que são mais do que reações animais e cumprimento de funções, são inteiramente supérfluos a regimes totalitários. $\mathrm{O}$ totalitarismo aspira não ao domínio despótico sobre os homens, mas a um sistema no qual os homens sejam supérfluos. O poder total pode ser alcançado e resguardado apenas em um mundo de reflexos condicionados, de marionetes sem o menor traço de espontaneidade. Precisamente porque os recursos do homem são tão grandes, ele pode ser completamente dominado somente quando se torna um espécime do homem enquanto espécie animal. 
ARENDT, Hannah. Os campos de concentração

Portanto, o caráter é uma ameaça, e até mesmo as normas legais mais injustas são um obstáculo; mas a individualidade, na verdade qualquer coisa que distinga um homem do outro, é intolerável. Até que todos os homens não tenham se tornado igualmente supérfluos - e isso foi alcançado somente nos campos de concentração -, o ideal da dominação totalitária não foi alcançado. Estados totalitários buscam constantemente, apesar de nunca com sucesso completo, estabelecer a superfluidade do homem - pela seleção arbitrária de vários grupos para os campos de concentração, por purgação constante do aparato dominante, por liquidações em massa. O senso comum protesta desesperadamente que as massas são submissas e que todo esse gigantesco aparato de terror é, portanto, supérfluo; se fossem capazes de contar a verdade, os governantes totalitários responderiam: o aparato parece supérfluo a você somente porque serve para tornar os homens supérfluos.

Eles não falarão tão francamente. Mas os campos de concentração, e ainda mais as fábricas de cadáveres inventadas pelos nazistas, falam muito claramente. Hoje, com a população crescendo quase em toda parte, massas de pessoas estão constantemente sendo consideradas supérfluas por acontecimentos políticos, sociais e econômicos. Em tal época, os instrumentos criados para tornar seres humanos supérfluos estão fadados a oferecer uma grande tentação: por que não usar esses mesmos instrumentos para liquidar seres humanos que já se tornaram supérfluos?

Esse lado da questão é muito bem compreendido pelo senso comum das massas que, na maioria dos países, está muito desesperada para conservar muito medo da morte. Os nazistas, que tinham bastante ciência de que sua derrota não resolveria os problemas da Europa, sabiam exatamente o que estavam fazendo quando, ao final da guerra - a qual eles então sabiam que haviam perdido - montaram aquelas fábricas de aniquilamento que provaram ser a solução mais rápida possível ao problema das massas humanas supérfluas. Não há dúvida de que essa solução ocorrerá, de agora em diante, a milhões de pessoas sempre que pareça impossível minorar ao homem a miséria política, social ou econômica de uma maneira digna. 